\title{
Retroauricular pain caused by Eagle syndrome: A rare presentation due to compression by styloid process elongation
} \author{
Flávio Key Miura ${ }^{4}$, Vinicius Monteiro de Paula Guirado ${ }^{4}$, José Carlos Esteves Veiga ${ }^{5}$

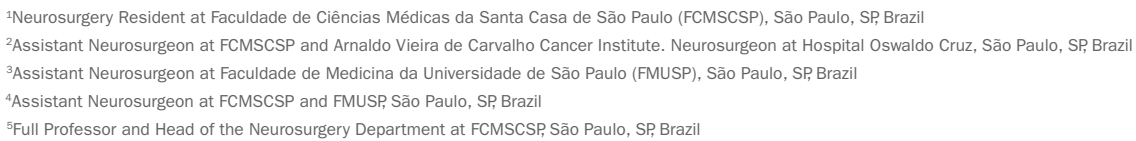

Aline Lariessy Campos Paiva ${ }^{1 *}$, João Luiz Vitorino Araujo², Renan Maximilian Lovato ${ }^{1}$, Joel Augusto Ribeiro Teixeira ${ }^{3}$,

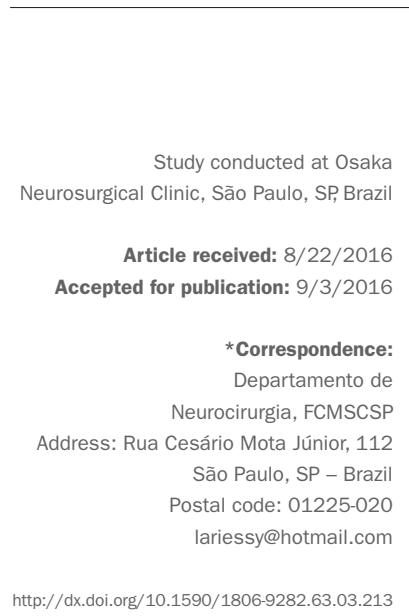

\section{SUMMARY}

Eagle syndrome is a rare condition presenting with retroauricular pain (usually as main symptom) associated with dysphagia, headache, neck pain on rotation and, much rarelier, stroke. This occurs due to styloid process elongation. Sometimes, there is also styloid ligament calcification, which can cause compression of nerves and arteries and the symptoms above. Treatment can be conservative with pain modulators (e.g. pregabalin) or infiltrations (steroids or anesthetics drugs). In refractory cases, surgical approach aiming to reduce the size of the styloid process can be performed. We present a rare case of Eagle syndrome (documented by computed tomography) with good response to clinical treatment.

Keywords: Eagle syndrome, deglutition disorders, retroauricular pain.

\section{CAse RePort}

A 48-year-old female patient without previous medical history presented to a neurosurgical clinic with a complaint of right retroauricular and occipital pain for several years. She denied any previous traumas and characterized it as a stabbing pain that worsens with lateral rotation of the head associated with dysphagia and occasionally with tinnitus. Her neurological examination was normal and she only complained of tenderness during palpation of right retroauricular region.

Complementary investigation with computed tomography (CT) scanning revealed styloid process elongation compatible to Eagle syndrome (Figure 1). W.W. Eagle first described the syndrome in $1937,{ }^{1}$ associating styloid process elongation and styloid ligament calcification with retroauricular and facial pain, odynophagia, headache and, in rare cases, stroke (due to carotid compression). ${ }^{2}$ Styloid elongation may not cause symptoms, appearing as incidental finding on CT scans in approximately $4 \%$ of the general population. ${ }^{2,3}$ The clinical syndrome with symptoms and compatible CT findings is very rare.

Treatment can be surgical or conservative. A first attempt can be made with pain modulators, such as pregabalin and gabapentin, and anesthetic or steroid infiltration in the affected region. ${ }^{4}$ Usually, this reduces pain for a short period of time. However, if the mechanical factor is substantial, this approach will not suffice. The most effective treatment then would be surgical, with sectioning of the styloid process in order to cease the compression factor. ${ }^{4,5}$

Our patient received conservative treatment alone with $150 \mathrm{mg}$ of pregabalin per day. She is being monitored with periodical consultations (treatment was initiated several months ago). She referred complete resolution of her pain few weeks after pregabalin initiation and has no limitations for daily activities.

\section{Resumo}

Dor retroauricular causada pela síndrome de Eagle: uma apresentação rara por compressão pelo alongamento do processo estiloide

A síndrome de Eagle é uma condição rara na qual ocorre dor retroauricular (usualmente é o principal sintoma) associada a disfagia, cefaleia, cervicalgia durante a ro- 


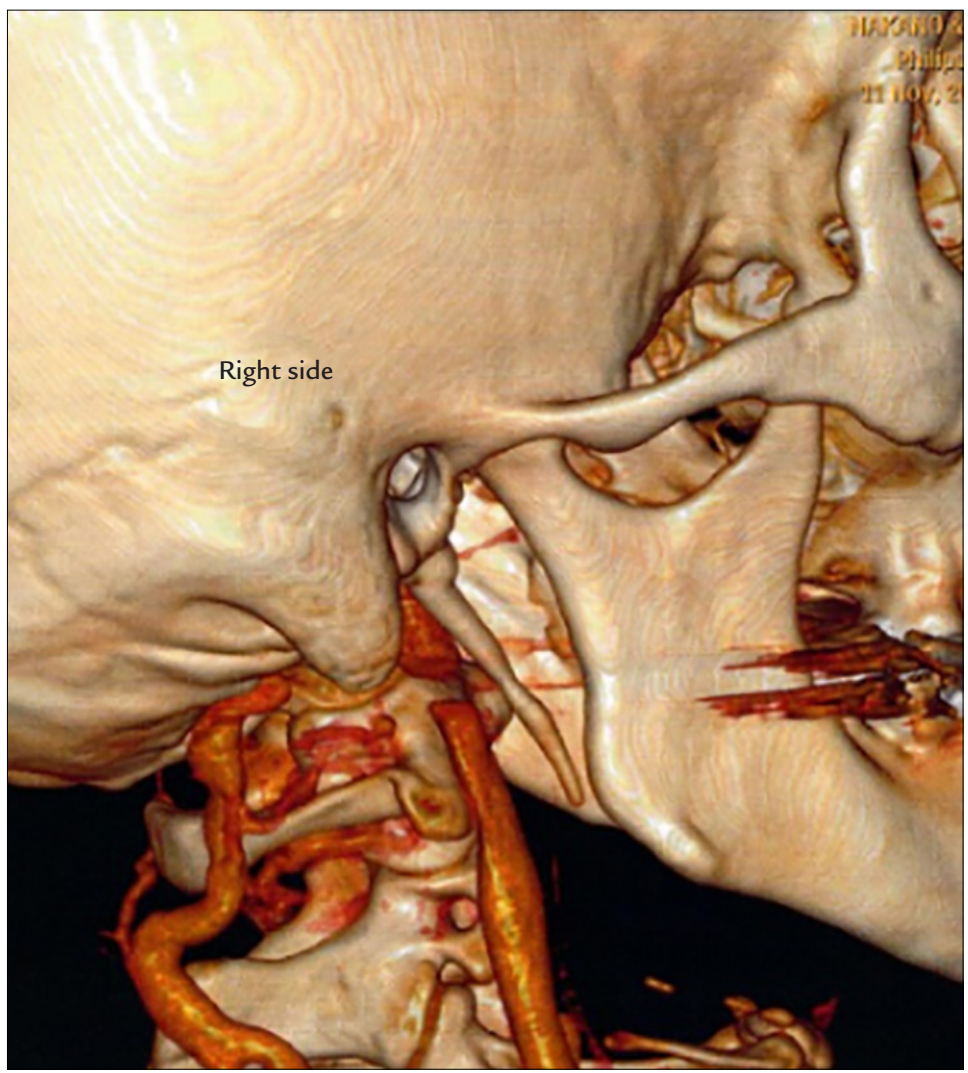

FIGURE 1 3D CT showing right styloid process elongation.

tação da cabeça e, mais raramente, a AVC. Isso ocorre por conta do alongamento do processo estiloide e, às vezes, há também calcificação do ligamento estiloide. Essas estruturas podem comprimir nervos e artérias causando os sintomas citados. O tratamento pode ser conservador com moduladores da dor, como pregabalina, ou com infiltrações (corticoides ou drogas anestésicas). Em casos refratários, cirurgia para reduzir o tamanho do processo estiloide pode ser realizada. É apresentado um caso raro de síndrome de Eagle (documentado com tomografia computadorizada) com boa resposta ao tratamento clínico.
Palavras-chave: síndrome de Eagle, distúrbios da deglutição, dor retroauricular.

\section{REFEREnCES}

1. Fusco DJ, Asteraki S, Spetzler RF. Eagle's syndrome: embryology, anatomy, and clinical management. Acta Neurochir (Wien). 2012; 154(7):1119-26.

2. Han MK, Kim DW, Yang JY. Non-surgical treatment of Eagle's syndrome a case report. Korean J Pain. 2013; 26(2):169-72.

3. Gokce C, Sisman Y, Sipahioglu M. Styloid process elongation or Eagle's syndrome: is there any role for ectopic calcification? Eur J Dent. 2008; 2(3):224-228.

4. Murtagh RD, Caracciolo JT, Fernandez G. CT findings associated with Eagle syndrome. AJNR Am J Neuroradiol. 2001; 22(7):1401-02.

5. Tiago RSL, Marques Filho MF, Maia CAS, Santos OFS. Síndrome de Eagle: avaliação do tratamento cirúrgico. Rev Bras Otorrinolaringol. 2002; 68(2):196-201. 